\title{
Sistem Informasi Arsip Digital Kartu Catatan Siswa Berbasis Web
}

Budi Hartono ${ }^{1}$, Danang ${ }^{2}$, Muh Tofik ${ }^{3}$

${ }^{1,3}$ Fakultas Komputer dan Bisnis, Universitas STEKOM,

${ }^{2}$ Fakultas Ilmu Terapan, Universitas STEKOM

${ }^{1}$ budi@stekom.ac.id , 2 danang@ @stekom.ac.id, , ${ }^{3}$ taufiqqurrohman@gmail.com

\section{ARTICLE INFO}

Article history:

Received : 7 - September - 2021

Received in revised form : 7 - Oktober - 2021

Accepted : 11 - Oktober - 2021

Available online : 16 - Oktober - 2021

\begin{abstract}
The purpose of this research is to build a Web-Based Digital Archive Information System for Student Record Cards. This application is to help the system of managing and controlling student record data which was originally still done manually in the SMK Negeri 5 Semarang environment. Problems when managing and searching for old archives contained in notes in other books which are located partially from month to month each month.

This research uses a research and development approach or Research and Development with reference to Soegiyano's RND stage. This stage starts from the potential and problem stage, data collection, to the product implementation stage, so that it can produce accurate data when reporting problematic student records and determining warning letters and calls to parents and guardians of students.
\end{abstract}

Keywords: Information Systems, Digital Archives, Student Record Cards, WEB-Based, R\&D Method.

\begin{abstract}
Abstrak
Tujuan penelitian ini adalah membangun Sistem Informasi Arsip Digital Kartu Catatan Siswa Berbasis Web. Aplikasi ini untuk membantu sistem pengelolaan dan pengendalian data catatan siswa yang semula masih dilakukan secara manual di lingkungan SMK Negeri 5 Semarang. Permasalahan pada saat mengelola dan mencari arsip lama yang terdapat dalam catatan pada buku-buku lainnya yang terletak parsial dari bulan ke bulan pada setiap bulanya.

Penelitian ini dengan menggunakan pendekatan penelitian dan pengembangan atau Research and Development dengan merujuk pada tahapan RND milik Soegiyano. Tahap ini di mulai dari tahap potensi dan masalah, pengumpulan data, sampai pada tahap implementasi produk, sehingga dapat menghasilkan data yang akurat saat melaporkan catatan siswa bermasalah dan menentukan surat peringatan dan pemanggilan terhadap orang tua wali murid.
\end{abstract}

Kata Kunci : Sistem Informasi, Arsip Digital, Kartu Catatan Siswa, Berbasis WEB, Metode R\&D.

\section{Pendahuluan}

Sekolah merupakan instansi yang bergerak dalam bidang pendidikan yang menerapkan komputerisasi guna menunjang kelancaran dalam mengelola data siswa. Tetapi penulis melihat masih tidak akuratnya informasi data yang terjadi pada SMK Negeri 5 Semarang, yang beralamat di JL. Dr. Cipto 121 
Semarang, mengenai pengolahan informasi data dan juga terjadi keterlambatan informasi yang diharapkan, karena teradapat aliran data yang kurang efisien dalam rekapitulasi dan arsip catatan pelanggaran siswa yang terjadi pada bidang kesiswaan sehingga proses berjalan dengan lambat karena sistem rekapitulasi dan arsipnya masih menggunakan catatan tertulis secara manual. Siswa yang terlambat lebih dari tiga kali maka akan dipanggil orang tuanya, apabila dalam satu bulan bisa terdeteksi, namun jika hal ini terjadi dalam kurun waktu yg agak lama kadang tidak terdeteksi, contoh kasus: seorang siswa bulan januari terlambat dua kali kemudian bulan maret terlambat satu kali, bulan april terlambat dua kali, hal ini tidak terdeteksi pada sistem manual, karena harus membuka kembali catatan lama, sehingga hal ini biasanya diabaikan, karena memerlukan banyak waktu untuk membaca dan membuka kembali catatan yang lama.

Setelah mengetahui kondisi tersebut, penulis mempunyai solusi untuk memecahkan permasalahan tersebut dengan membuat atau merancang suatu sistem informasi dalam pengolahan data tersebut. Dengan melihat kondisi yang ada terdapat 1 unit komputer di ruang BK dan 2 unit di ruang Kesiswaan yang terkoneksi dengan Internet, yang peruntukannya saat ini digunakan untuk mengerjakan administrasi Belajar dan Mengajar maka dapat dimanfaatkan pula sebagai Sistem Informasi berbasis Web.

Berapa penelitian telah dilakukan oleh Endri Cahyaningrum (2016) dan Andika Kresna Aditya (2017), dengan penjabaran masing-masing sebagai berikut :

Endri Cahyaningrum (2016), dengan judul Skripsi Rancang Bangun Aplikasi Monitoring Pelanggaran Siswa Di SMK Muhammadiyah 1 Sragen. Bertujuan dapat mempermudah pekerjaan Guru BK, dan dapat menjadi acuan buat siswa yang sudah melakukan pelanggaran, sehingga siswa bisa mengontrol agar tidak mencapai batas maksimum, dan yang terpenting adalah tidak terjadi penumpukan data, dengan solusi Membuat Rancang Bangun Aplikasi Monitoring Pelanggaran Siswa Di SMK Muhammadiyah 1 Sragen yang dapat memudahkan pengguna untuk menentukan kategori pelanggaran dan sanksi yang akan diberikan kepada siswa. Selain itu, dapat dijadikan sebagai acuan dalam meningkatkan kedisiplinan siswa. Aplikasi monitoring pelanggaran siswa ini hanya dapat di gunakan oleh Admin selaku Guru Bk/Bp dan siswa aktif SMK Muhammadiyah 1 Sragen yang telah mempunyai username dan password

Andika Kresna Aditya (2017), dengan judul Pengembangan dan Analisis Sistem Informasi Pelanggaran Siswa Berbasis Web pada SMA Negeri 2 Pati. Bertujuan menyimpan dan mengelola data pelanggaran siswa sehingga pencarian dan pemrosesan data menjadi lebih mudah dan tersusun. Web atau website adalah media yang tepat untuk mengimplementasikan sistem informasi ini. Selain mampu menyimpan dan mengelola data, web juga akan mempermudah siswa dan mengakses data pelanggaran siswa, dengan solusi Membuat sebuah Pengembangan Dan Analisis Sistem Informasi Pelanggaran Siswa Berbasis Web.

\section{LANDASAN TEORI}

Arsip digital adalah arsip yang diciptakan dan digunakan dalam bentuk elektronik. Arsip digital dapat berasal dari arsip tercetak yang dikonversi menjadi digital atau arsip yang memang "lahir" dalam bentuk digital. Dalam mengelola arsip digital yang merupakan hasil alih media dari arsip tercetak. Tata cara pengelolaannya mengikuti bentuk asalnya. Sehingga apabila arsip tercetaknya sudah perlu untuk dimusnahkan, maka bentuk digitalnya juga perlu dimusnahkan. Karena pada dasarnya kegiatan mengalih media arsip adalah hanya untuk membantu dalam melestarikan arsip tersebut.

Hal lain yang perlu dipertimbangkan dalam mengelola arsip digital adalah:

a) Format digital, teknologi berkembang sangat cepat, oleh karena itu perlu dipastikan bahwa format digital yang digunakan masih dapat digunakan

b) Akses dan keamanan, akses yang mudah menurunkan tingkat keamanan, sedangkan tingkat keamanan yang tinggi akan menyulitkan akses. Kedua hal tersebut perlu diseimbangkan.

c) Temu kembali, temu kembali arsip digital seharusnya menjadi lebih mudah dibandingkan dengan arsip tercetak. Maka dari itu perlu diperhatikan penggunaan metadata yang merupakan titik akses untuk temu kembali arsip.

Kartu catatan siswa yang memuat jati diri seseorang sebagai tanda ke- anggotaan suatu perkumpulan dalam hal ini adalah Siswa yang tercatat sebagai siswa di SMK Negeri 5 Semarang.

Website adalah suatu halaman Web yang saling berhubungan yang umumnya berisikan kumpulan informasi berupa data teks, gambar, animasi, audio, video maupun gabungan dari semuanya yang biasanya

JURNAL ILMIAH TEKNOLOGI INFORMASI DAN KOMUNIKASI (JTIK) VOL 12, No.2, September 2021 , pp. 1 - 11 
dibuat untuk personal, organisasi dan perusahaan. Dari pengertian website tersebut dapat dibedakan menjadi 2 yaitu web bersifat statis dan dinamis. Bersifat statis apabila isi informasinya tetap dan isi informasinya hanya dari pemilik website sedangkan web yang bersifat dinamis apabila isi informasinya selalu berubah-ubah dan dapat diubah-ubah oleh pemilik maupun pengguna website. Contoh web statis : website profil perusahaan, sedangkan contoh web dinamis seperti facebook, twitter dll.

www atau the Web atau World Wide Web adalah sama. Kita sering sekali menyebut bahwa web (baca: the web) dan websiteitu sama, padahal adalah dua hal yang berbeda. Web adalah nama yang diberikan untuk semua bagian internet yang dapat diakses dengan software web browser. Semua konten yang ada dalam web diformat kedalam Hypertext Markup Language(HTML). Sederhananya web adalah sebutan secara umum untuk semua bagian yang dapat kita akses menggunakan aplikasi web browser seperti Chrome, Firefox, Safari, dll.

Adapun cara kerja web adalah sebagai berikut:

a) Informasi web disimpan dalam dokumen dalam bentuk halaman-halaman we atau web page.

b) Halaman web tersebut disimpan dalam computer server web.

c) Sementara dipihak pemakai ada computer yang bertindak sebagai computer client dimana ditempatkan program untuk membaca halaman web yang ada di server web (browser).

d) Browser membaca halaman web yang ada di server web.

Localhost merupakan istilah dalam komputer jaringan yang berarti komputer ini. localhost adalah nama standar yang diberikan sebagai alamat loopback network interface. Localhost selalu menerjemahkan loopback ip address 127.0.0.1 dalam IPv4, atau dalam IPv6. Localhost digunakan untuk mengantarkan web browser pada HTTP server yang terinstall di komputer lokal. Alamat http://localhost akan menampilkan website lokal pada komputer yang bersangkutan. Jadi, ketika komputer 1 sebagai localserver dan lainnya sebagai client, kemudian menghostingkan web didalamnya (localhost) untuk dijadikan tempat membangun website sementara dan kemudian dihostingkan secara online ke internet. Dengan demikian menjadikan komputer kita sebagai localserver, kita dapat bekerja secara offline tanpa harus takut menghadapi masalah biaya, waktu, dan kenyamanan.

Pengertian XAMPP adalah perangkat lunak (free software) bebas, yang mendukung untuk banyak sistem operasi, yang merupakan kompilasi dari beberapa program. Fungsi XAMPP sendiri adalah sebagai server yang berdiri sendiri (localhost), yang terdiri beberapa program antara lain : Apache HTTP Server, MySQL database, dan penerjemah bahasa yang ditulis dengan bahasa pemrograman PHP dan Perl.

Program ini tersedia dalam GNU General Public License dan bebas, merupakan web server yang mudah untuk digunakan yang dapat menampilkan halaman web yang dinamis. Untuk mendapatkanya XAMPP anda dapat mendownload langsung dari web resminya. Dan berikut beberapa definisi program lainnya yang terdapat dalam XAMPP.

Nama XAMPP sendiri merupakan singkatan dari X (empat sistem operasi apapun), Apache, MySQL, PHP dan Perl. Masing-masing huruf yang ada di dalam nama XAMPP memiliki arti sebagai berikut ini:

$\mathrm{X}=$ Cross Platform - Merupakan kode penanda untuk software cross platform atau yang bisa berjalan di banyak sistem operasi.

$\mathrm{A}=$ Apache - Apache adalah aplikasi web server yang bersifat gratis dan bisa dikembangkan oleh banyak orang (open source).

M = MySQL / MariaDB - MySQL atau MariaDB merupakan aplikasi database server yang dikembangkan oleh orang yang sama. MySQL berperan dalam mengolah, mengedit, dan menghapus daftar melalui database.

$\mathrm{P}=$ PHP - Huruf "P" yang pertama dari akronim kata XAMPP adalah inisial untuk menunjukkan eksistensi bahasa pemrograman PHP. Bahasa pemrograman ini biasanya digunakan untuk membuat website dinamis, contohnya dalam website berbasis CMS WordPress.

$\mathrm{P}=$ Perl - Sementara itu, untuk huruf $\mathrm{P}$ selanjutnya merupakan singkatan dari bahasa pemrograman Perl yang kerap digunakan untuk memenuhi berbagai macam kebutuhan. Perl ini bisa berjalan di dalam banyak sistem operasi sehingga sangat fleksibel dan banyak digunakan.

Istilah SQL dapat diartikan sebagai suatu bahasa yang digunakan untuk mengakses suatu data dalam database relasional dan terstruktur sedangkan MySQL dalam hal ini menjadi software atau tools untuk mengelola atau memanajemen SQL dengan menggunakan Query atau Bahasa khusus. Pada dasarnya database yang dikelola dalam MySQL memang tidak jauh berbeda dari Microsoft Acces yakni berbentuk tabel - tabel yang berisi informasi tertentu. Perbedaannya terletak pada penggunaan serta pengelolaan database tersebut. 
MySQL ini tergolong suatu software yang open source dan berlisensi GPL atau General Public License. Lisensi GPL ini hanya ditujukan pada perangkat lunak tertentu untuk keperluan proyek GNU, inilah yang menjadi faktor banyaknya pengguna MySQL di seluruh dunia. Selain mudah digunakan, anda dapat mengelola data dengan lebih efektif karena menggunakan script atau Bahasa tertentu dan secara otomatis akan menjadi perintah ke sistem.

Sebelumnya sudah sempat dibahas bahwa secara garis besar MySQL digunakan untuk membuat dan mengelola suatu database secara terstruktur dan otomatis menggunakan suatu Bahasa khusus. Namun lebih jelasnya lagi MySQL ini memberikan kemudahan bagi para pengguna yang ingin mengelola suatu data yang berisi informasi secara String (text based) dan dapat diakses secara pribadi maupun untuk umum dalam suatu web. Hampir semua host atau penyedia server web memberikan fasilitas MySQL untuk para developer web yang menginginkan pengelolaan database di websitenya.

Dalam dunia website, bentuk interface atau tatap muka untuk MySQL ini sering disebut dengan phpMyAdmin. Inilah yang menjadi salah satu faktor adanya keterkaitan antara Bahasa PHP dengan MySQL terutama dalam hal pengelolaan web. Beberapa contoh penerapan MySQL juga dapat dijumpai pada E-Commerce, situs Blog ataupun suatu CMS (WordPress, Joomla, dan lain - lain).

\section{METODE PENELITIAN}

Jenis penelitian yang digunakan dalam penelitian ini adalah pendekatan penelitian dan pengembangan atau Research and Development. dalam penelitian ini adalah model waterfall. Model waterfall dimulai dari tahap analisis kebutuhan, tahap desain, tahap implementasi, dan tahap pengujian produk.

Pengumpulan data yang digunakan dalam penelitian ini adalah :

a. Wawancara

Wawancara dilaksanakan antara peneliti dengan beberapa guru di SMK Negeri 5 Semarang. Dalam wawancara ini dapat diketahui karakteristik dari peserta didik yang sering terlambat masuk sekolah dan melakukan pelanggaran terhadap tata tertib sekolah, permasalahan tersebut diduga kuat karena selama ini penanganan siswa terlambat sekolah masih menggunakan teknik/cara manual dengan mencatat di buku laporan. Dari hasil wawancara tersebut kemudian peniliti berasumsi bahwa pengembangan aplikasi Sistem Informasi Arsip Digital Kartu Catatan Siswa Berbasis WEB sangat tepat diterapkan di sekolah tersebut.

\section{b. Observasi}

Pengamatan langsung merupakan teknik pengumpulan data yang dilakukan peneliti dengan terlebih dahulu menetapkan tingkah laku yang akan diteliti, kemudian memikirkan prosedur sistematis untuk menetapkan, menggolongkan, dan mencatat tingkah laku itu baik dalam situasi yang wajar maupun buatan. Observasi dilakukan peneliti ketika proses Kegiatan sekolah sedang berlangsung, observasi dilakukan dengan tujuan mengetahui proses siwa datang masuk sekolah secara langsung dan pengamatan terhadap proses penerapan disiplin terhadap pelaksanaan tata tertib sekolah khususnya bagi siswa yang terlambat masuk sekolah..

\subsection{Waktu dan Tempat Pelaksanaan}

Waktu yang digunakan untuk menyelesaikan skripsi "Sistem Informasi Arsip Digital Kartu Catatan Siswa Berbasis Web", kurang lebih selama 6 bulan (April - September 2020 ) Penelitian dan pengujian Skripsi ini dilakukan di SMK Negeri 5 Semarang yang beralamat di JL. Dr. Cipto 121 Semarang. Penilaian Aplikasi ini menggunakan kuisioner.

\subsection{Alat dan Bahan}

Peralatan yang digunakan berupa software dan hardware. Software yang digunakan antara lain Xampp, Sublime Text Build 3211 x64, PHP, Web Browser, dan MySQL Database. Sedangkan untuk Hardware yang digunakan adalah satu buah laptop dengan spesifikasi processor Intel Core i3, JURNAL ILMIAH TEKNOLOGI INFORMASI DAN KOMUNIKASI (JTIK) VOL 12, No.2, September 2021, pp. 1 - 11 
RAM 4 GB, Harddisk 500 GB, Sistem Operasi Windows 10 dan Modem buat koneksi ke internet, Sedangkan untuk bahan yang digunakan untuk penelitian adalah seluruh siswa aktif SMK Negeri 5 Semarang.

\subsection{Perancangan Sistem}

Diagram yang digunakan pada aplikasi monitoring pelanggaran siswa ini diantaranya : Flowchart dan use case diagram

a. Langkah-langkah penelitian $\mathrm{R} \& \mathrm{D}$ dapat dilihat dari gambar bagan dibawah ini :

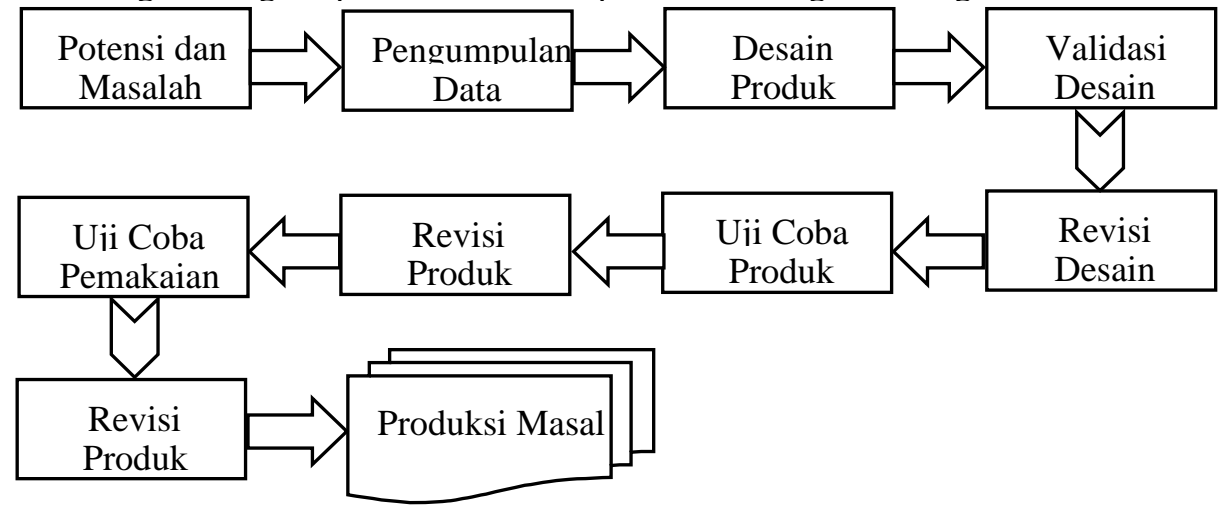

Gambar 2. Diagram Alur Langkah-langkah Penelitian R\&D

\subsection{Desain DFD (Data Flow Diagram)}

Data Flow Diagram (DFD) merupakan suatu cara atau metode untuk membuat rancangan sebuah sistem yang mana berorientasi pada alur data yang bergerak pada sebuah sistem nantinya. Dalam pembuatan Sistem Informasi, a) Diagram konteks
a Diagram Dekomposisi
b DFD ( Data Flow Diagram)
c DFD Level 1 Pendataan
d DFD Level 1 Proses
e DFD Level 1 Laporan

\subsection{Perancangan Basis Data}


6

ERD (Entry Relational Diagram)

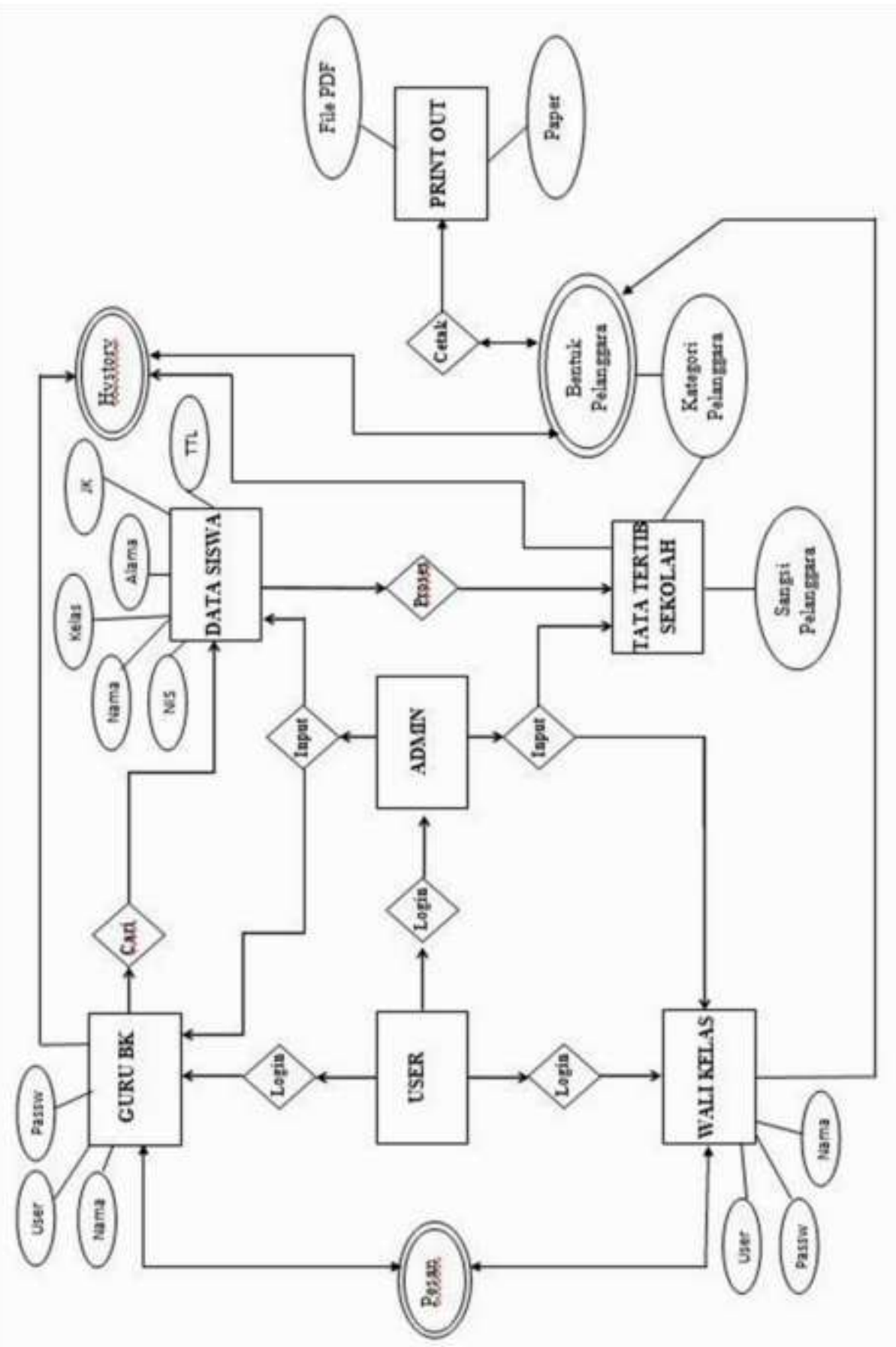

3.6 Perancangan Interface

a) Tampilan Awal

JURNAL ILMIAH TEKNOLOGI INFORMASI DAN KOMUNIKASI (JTIK) VOL 12, No.2, September 2021, pp. $1-11$ 


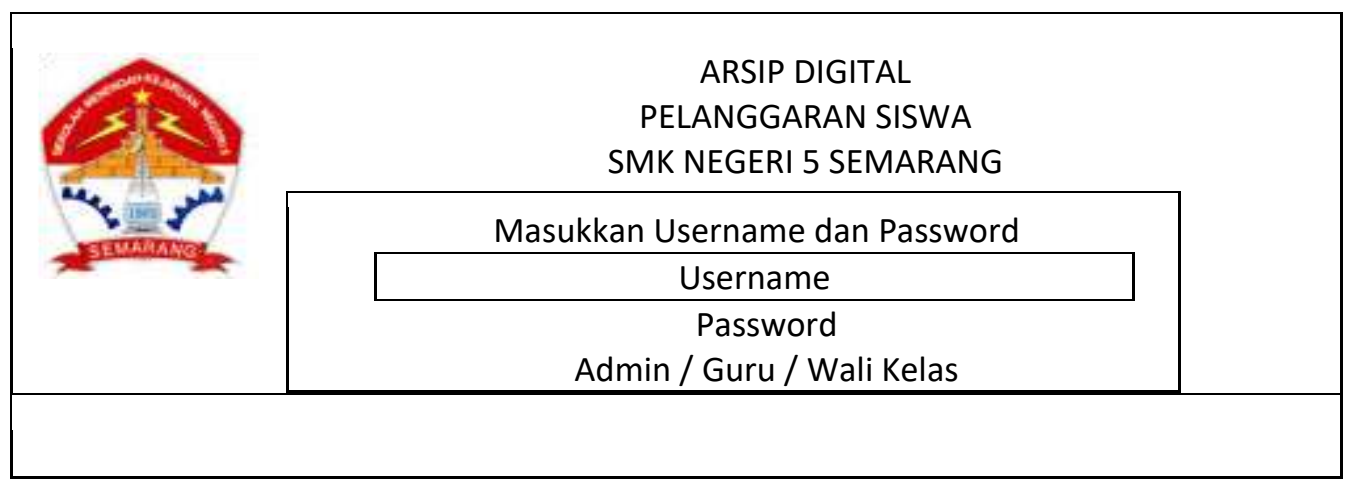

b) Menu Utama

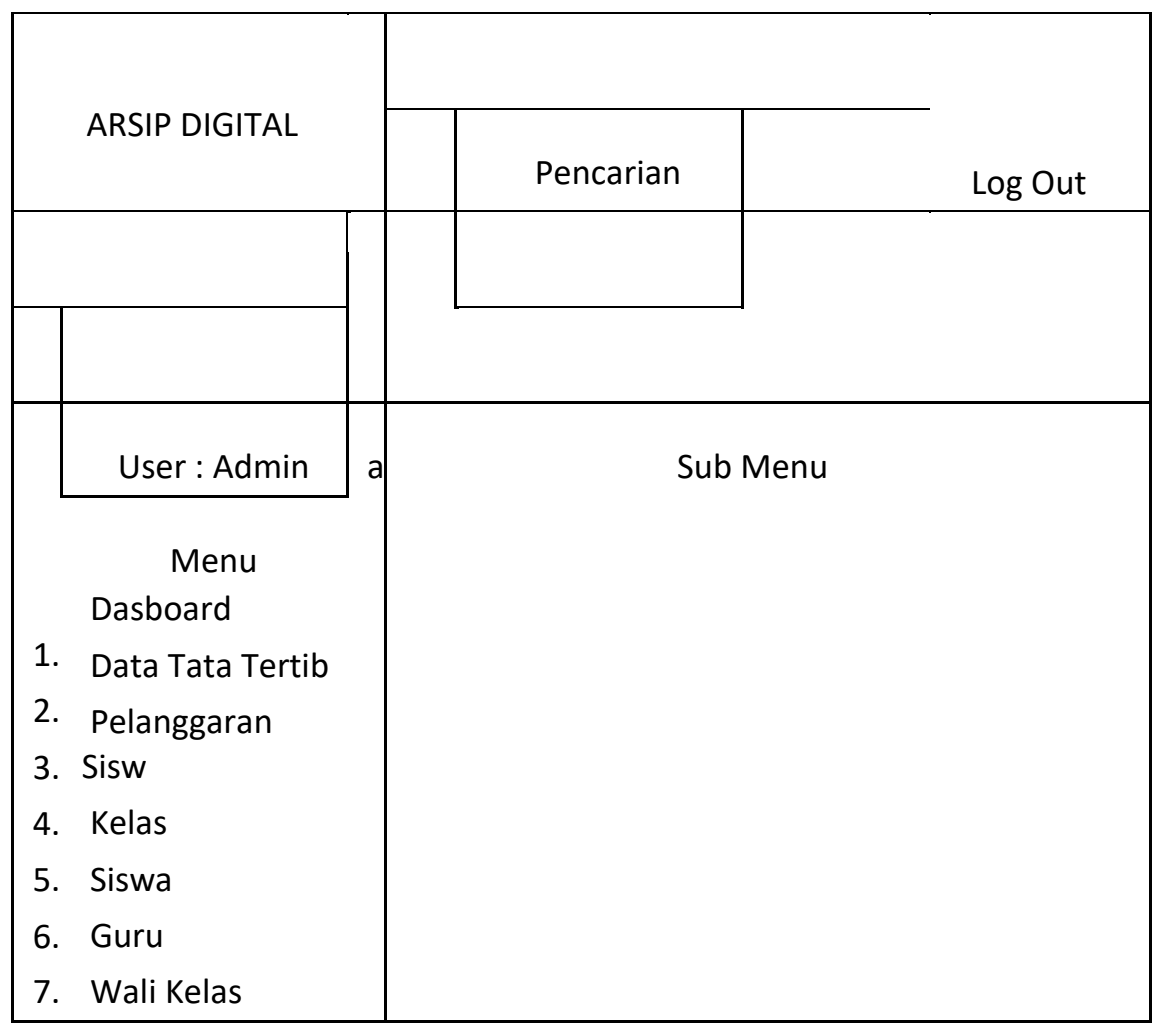

c) Menu Guru

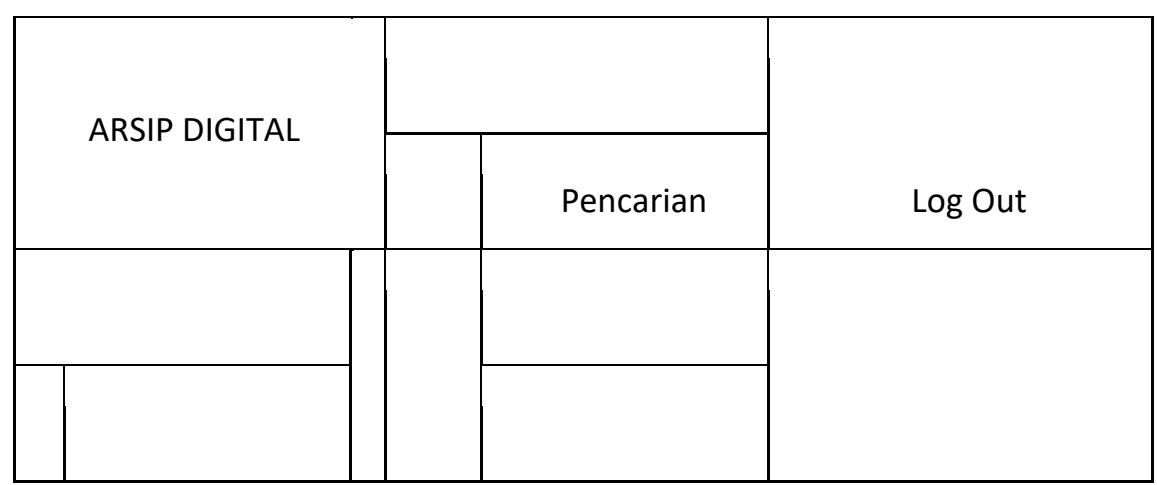




\begin{tabular}{|l|l|l|}
\hline \multicolumn{1}{|c|}{ User: Guru } & & Menu \\
1. & Dasboard \\
1. & Input Pelanggara & \\
2. Sanksi & Sub \\
3. Pelanggaran & \\
4. & Wali Murid & \\
5. History & \\
\hline
\end{tabular}

d) Menu Wali Kelas

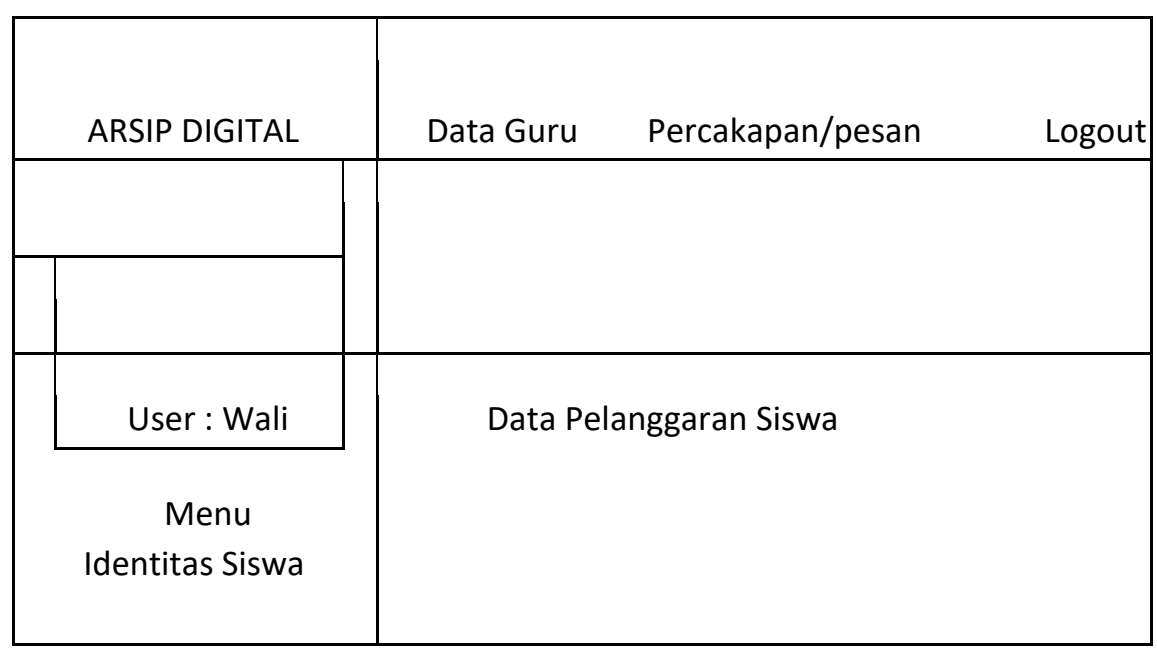

\section{HASIL DAN PEMBAHASAN}

a. Software Pendukung

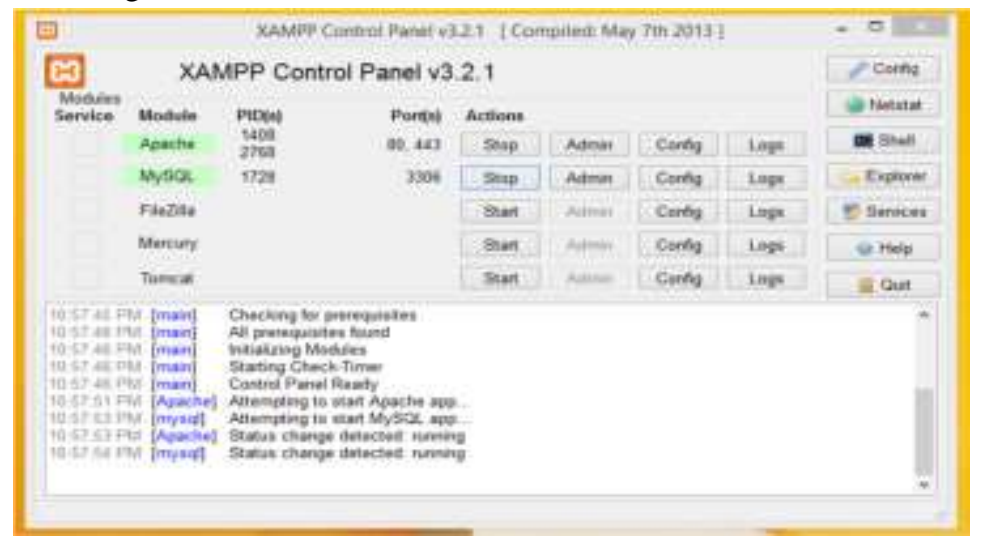

JURNAL ILMIAH TEKNOLOGI INFORMASI DAN KOMUNIKASI (JTIK) VOL 12, No.2, September 2021, pp. 1 - 11 
Fungsi XAMPP sebagai server yang berdiri sendiri (localhost), yang terdiri beberapa program antara lain : Apache HTTP Server, MySQL database, dan penerjemah bahasa yang ditulis dengan bahasa pemrogramann PHP dan Perl.

Tabel pada phpMyAdmin

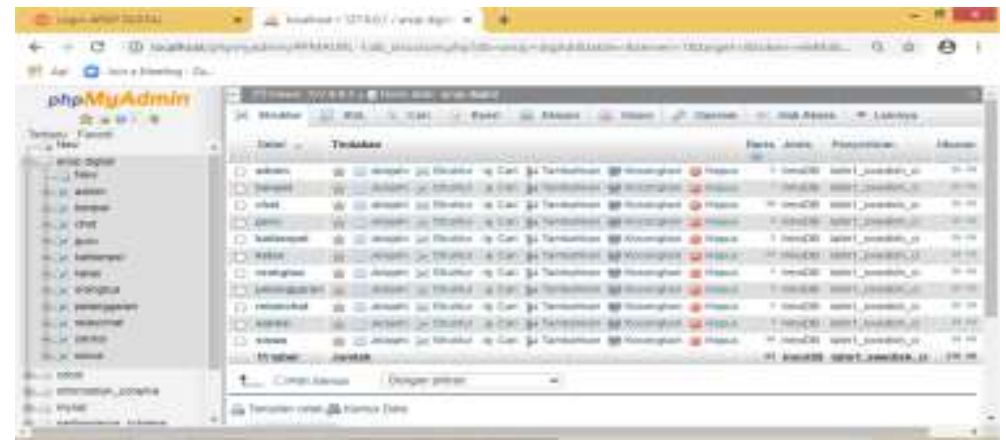

Tabel Arsip Digital melalui phpMvadmin

Pada phpMyadmin ini untuk menampilkan tabel-tabel terkai dengan arsip digital diataranya adalah tabel guru, tebel siswa, tabel sanksi, tabel, kelas , dll, tabel-tabel ini berfungsi untuk menyimpan data sesuai dengn dengan nama tabel yang ada.

a. Tampilan Halaman Login

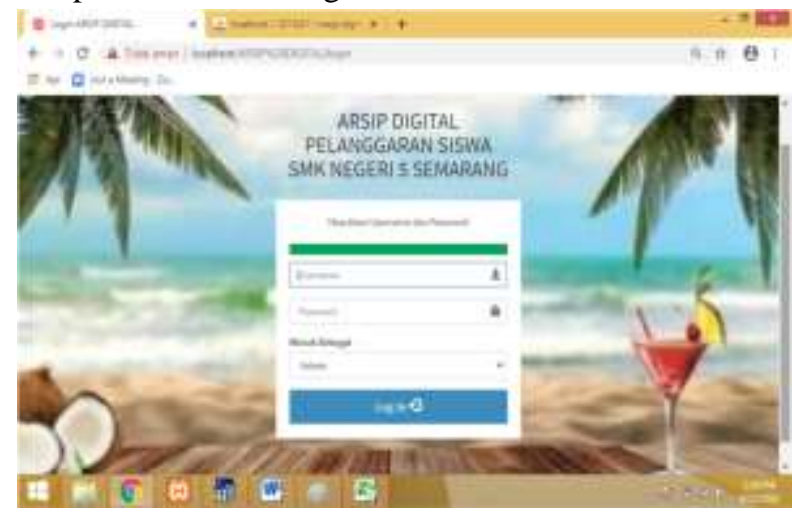

Ini adalah tampilan awal untuk masuk ke sebuah sistem arsip digital, menyakan tentang hak akses penggunanya, sesuai atau tidak.

b. Tampilan Halaman Login

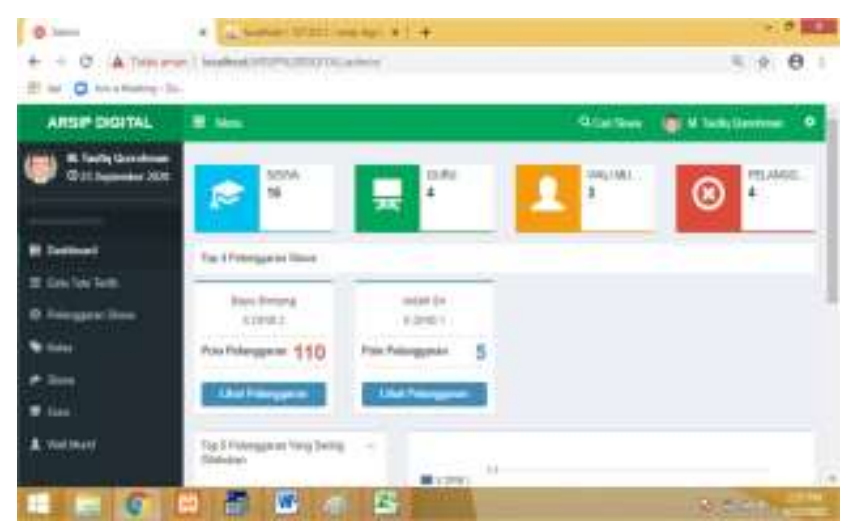


Setelah berhasil masuk ke login, selajutnya akan tampil menu utama sistem arsip digital, pada menu ini terdiri dari Dasboard, data tata tertib, pelanggaran siswa, kelas, siswa, guru dan wali murid. Pada menu utama ini juga menampilkan informasi mengenai jumlah siswa, jumlah guru, wali murid dan juga jumlah pelanggaran, serta jumlah point pelanggaran tertinggi oleh siswa.

c. Tampilan Halaman Dasboard (Admin)

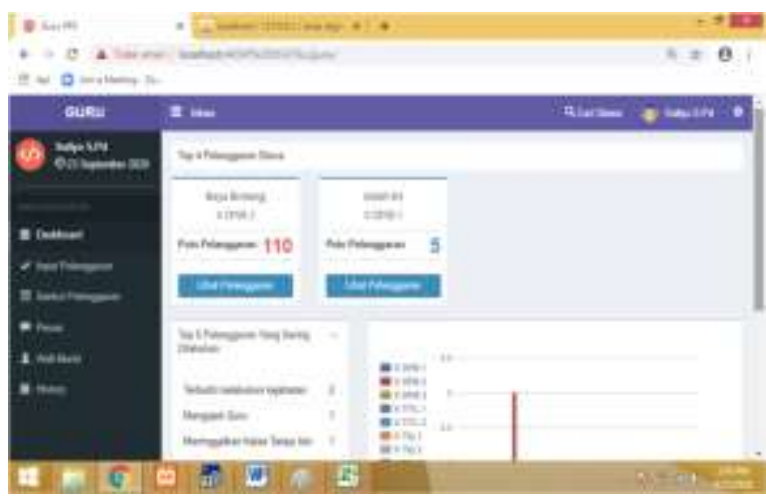

Gambar diatas adalah tampilan dari menu guru, yang menampilkan inoformasi mengenai jumlah siswa yang melanggar paling banyak dan grafik data kelas siswa yang melanggar.

d. Tampilan Halaman Dasboard (Guru)

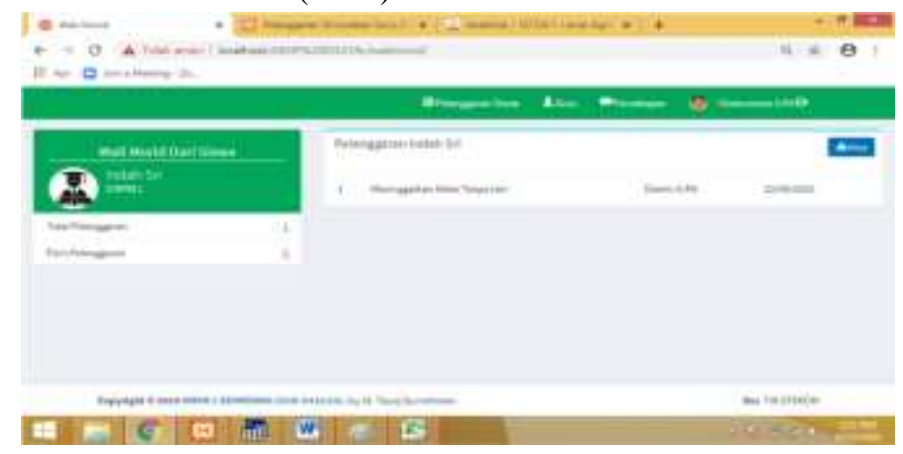

Berikut adalah informasi dari wali murid dari siswa yang berisikan pelanggaran dari siswa yang bersangkutan, siswa ini melakukan pelanggaran apa.

e. Tampilan Halaman Printout Pelanggaran Siswa

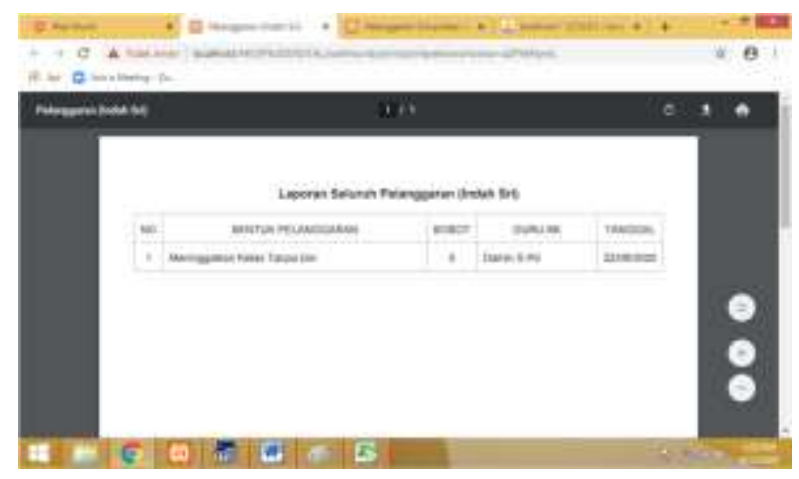

JURNAL ILMIAH TEKNOLOGI INFORMASI DAN KOMUNIKASI (JTIK) VOL 12, No.2, September 2021 , pp. 1 - 11 
Ini adalah laporan penggaran siswa yang berisi informasi dari siswa yang melanggar yang akan disampaikan pada orang tua dari siswa tersebut

\section{SIMPULAN DAN SARAN}

a. Simpulan Tentang Produk

Sistem Informasi Arsip Digital Kartu Catatan Siswa Berbasis Web adalah sebuah Aplikasi yang bekerja menggunakan server local dalam hal ini adalah localhost yang didapat dari XAMPP, sehingga semua informasi atau data yang diinputkan tersimpan aman pada jaringan lokal atau Komputer Lokal.

Aplikasi ini dibuat secara sederhana untuk mempermudah antar muka (Interface) User dan Komputer, sehingga memudahkan dalampproses input maupun cetak (printout) outputnya, sehingga semua user dapat menggunakannya dengan mudah.

Sistem pencarian Aplikasi ini berbasis / mengacu pada NIS ( Nomer Induk Siswa ) dan Nama Siswa, selain itu dibantu juga dengan menggunakan hardware berupa barcode scanner 1 Dimensi, hal ini karena didukung dengan kartu pelajar yang sudah tercetak dengan menggunakan Bacode 1 Dimensi yang bisa terbaca berupa angka NIS dari masing-masing Siswa.

\section{b. Keterbatasan Hasil Penelitian}

Hasil Penelitian ini terbatas hanya pada Data yang diperoleh dari informasi Kesiswaan tentang data siwa yang telah melakukan pelanggaran ringan, sedang dan berat, sehingga tidak semua siswa tercover kedalam database Aplikasi, selain itu terkendala dengan adanya pandemi Virus Corona-19, sehingga penggunaannya terhambat dengan tidak diijinkannya semua siswa datang kesekolah untuk tatap muka dalam pembelajaran.

c. Saran

Dengan adanya Aplikasi Sistem Informasi Arsip Digital Kartu Catatan Siswa Berbasis Web, dapat membantu metode pencatatan pelanggaran siswa secara manual, yang selama ini berlangsung di SMK Negeri 5 Semarang, dan semoga kedepannya Aplikasi ini dapat disempurnakan dan dikembangkan kembali oleh semua pihak, terutama dalam bidang Pendidikan di STEKOM.

\section{DAFTAR PUSTAKA}

Abdul Kadir (2020), Dasar Pemrograman Web Dinamis Menggunakan PHP Revisi ke-2, Penerbit : Andi, Yogyakarta.

Andika Kresna Aditya (2017), Pengembangan Dan Analisis Sistem Informasi Pelanggaran Siswa Berbasis Web Pada Sma Negeri 2 Pati. Jurnal Pendidikan Teknik Informatika, Universitas Negeri Yogyakarta.

Endri Cahyaningrum (2016), Rancang Bangun Aplikasi Monitoring Pelanggaran Siswa Di SMK Muhammadiyah 1 Sragen. Jurnal Fakultas Komunikasi Dan Informatika, Universitas Muhammadiyah Surakarta.

H. Ary Setyadi (2020). http://oke.or.id. Modul Easycase-Debuging Program dengan EasyCase.

Hidayat. Taufik, (23 Juni 2015), "ERD (Entity Relationship Diagram)" [online], 2015, Available: http://www.ttaufikhidayat.com/berita64- ERD\%28Entity-RelationshipDiagram\%29.html

Puspitosari, Heni A (2010). Pemrograman Web Database dengan PHP dan MySQL Tingkat Lanjut . Penerbit : Skripta. Malang.

Sugiyono (2009), Metode Penelitian Kuantitatif, Kualitatif dan R\&D, Alfabeta, Bandung.

Sutarman (2007), Membangun Aplikasi Web Dengan Php Dan Mysql, Penerbit : Graha Ilmu, Yogyakarta 